Saudi Journal of Business and Management Studies Abbreviated Key Title: Saudi J Bus Manag Stud ISSN 2415-6663 (Print) |ISSN 2415-6671 (Online) Scholars Middle East Publishers, Dubai, United Arab Emirates Journal homepage: https://saudijournals.com

Original Research Article

\title{
Does Financial Risks Has Effects on The Performance of Deposit Money Banks in Nigeria?
}

\author{
Isedu, Mustafa Ph.D*, Erhabor, Osaruyi Jeffrey Ph.D
}

Department of Banking and Finance, Faculty of Management Sciences, Ambrose Alli University, Ekpoma, Edo State

\author{
DOI: $10.36348 /$ sjbms.2021.v06i03.004 \\ | Received: 21.02.2021 | Accepted: 15.03.2021 | Published: 25.03.2021 \\ *Corresponding author: Isedu, Mustafa Ph.D

\section{Abstract}

The core function of deposit money banks today is purely the efficient management of their risks portfolio investments in order to maximize shareholders' wealth, by guaranteeing safety, returns on depositors' funds and confidence in the system. The study empirically investigated the effects financial risks on the performance of deposit money banks in Nigeria. More specifically, changes in financial performance were examined on the basis of the relative effect of credit risk, liquidity risk, market risk, operational risk and bank size. The study specifically focused on 18 deposit money banks listed on the floor of the Nigerian Stock Market for a period of 19 years both statistical and econometric techniques were applied in the analysis of the data used in the study. Panel data analysis technique was used in the estimation of the specified model. The fixed effects being the best performing effect in the relationships was adopted in the empirical analysis. The findings of this study revealed that the combined effects of financial risks do not influence banks' performance negatively. More specifically, the results from the empirical analysis revealed that financial risk proxy by Credit risk does not have any significant relationship with financial performance of deposit money banks in Nigeria. Liquidity risk is a significant determinant of deposit money banks' performance in Nigeria in the period under investigation. The effect of market risk, interest rate risk and Operational risk did not in any way affect bank performance significantly in Nigeria.

Keywords: Bank size, Bank performance, Credit risk, Deposit money bank, Liquidity risk, Market risk, and Operational risk.

Copyright () 2021 The Author(s): This is an open-access article distributed under the terms of the Creative Commons Attribution 4.0 International License (CC BY-NC 4.0) which permits unrestricted use, distribution, and reproduction in any medium for non-commercial use provided the original author and source are credited.

\section{INTRODUCTION}

\section{Background to the Study}

Banks are very important and special institutions in every economy. The financial intermediary theory of banking states that banks exist because they perform certain special functions that other financial intermediaries cannot replicate. These special functions are the intermediating roles between savers (depositors) and the borrowers; that is, mobilizing idle financial resources from the surplus units (that is, savers, through the various accounting systems and bills discounting), and making this financial resources available to the deficit units (that is, fund seekers who are in need of funds - the borrowers) through loans and/or credits, and when they (the banks) invest in securities [1]. This credit creation function has remained the primary function and main business of every banking industry in the world and has helped in accelerating the pace of a nation's economic growth and its long-term sustainability. But, in performing and sustaining these intermediating roles, the banks are invariably exposed to risk that may have a potential direct and/or indirect influence on their performance [2, $3]$.

Risks in banking has been traced to the industrial revolution when projects required large capital outlays due to the fast growing commercial and production activities. Unable to meet these huge financial demands internally, many farmers, entrepreneurs and industrialists turned to the banks for help but many defaulted in repayment. In Nigeria, the emergence of indigenous banking (the era of free banking) in the 1900s saw many Nigerian nationalists 
Isedu, Mustafa et al., Saudi J Bus Manag Stud, Mar, 2021; 6(3): 71-85

and industrialists (including the late Dr. Nnamdi Azikiwe) establishing their own banks mainly to assist Nigerians to access loans, because they (the farmers, traders and entrepreneurs) were discriminated against by the foreign owned banks. These created huge bad debts when many of the farmers, traders and entrepreneurs just like their European counterparts also defaulted in their loan repayments, causing unprecedented loss to the economy and the resultant indigenous banks' failure and distresses that characterized the era of free banking.

Similarly, during the economic recessions in the 80 s and early 90 s, banks were highly motivated to grant credits to clients who could easily express their creditworthiness so as to stem up the economy [4]; and with the deregulation of the banking sector in the late 90s, the demands for credit by borrowers assumed an unprecedented level. Thus, large amount of bad credits, as a result of the boom-time advances in the 1980s and the 1990s also led to financial crisis and banks' failures $[5,6,4]$. The increasing deregulation in the banking sector in the 2000s coupled with high competitive level in the banking sector, and the globalization of financial activities, made banks to look beyond their primary role of not only the taking of deposits and making loans, but the introduction of new financial products to satisfy customers, and meet the increasing pressures for more profits; however, these have contributed to the build-up of vulnerabilities such as high debt levels, nonperforming loans and stretched asset valuations. According to Julian, Alworth \& Bhattacharya [7], the increasing competition in the banking sector which has resulted to the current waves of financial innovations and changing characters of banking activity that have swept through the financial system since the 2000s has exposed the banks to a greater variety of risks.

\section{SECTION TWO}

\section{The Risk theory of Profit}

This study is premised on the risk bearing theory of profit developed by Hawley [8]. This risk theory of profit is generally based on the risk and performance literature. Performance and financial risks are two components that have a two-way interaction. Each component is important to the other to sustain the operation of the firm. According to Hawley's risk theory of profit [8], profit is considered to be the return of risk as an additional factor of production and have a positive relationship with risk. This means that the higher the factor (that is, risk), the higher the profit and the higher the distributable return for the risk.

The theory posits that profit is a reward for risk taking, that some risks are inherent in every business enterprise in view of the speculative nature; thus in the business of banking, the management has to bear the risk in order to get profit being the reward for the risk taking. But, the degree of risk varies according to different businesses. However, there is a positive relationship between risk and profit. This idea is supported by Aaker and Jacobson [9], who argued that risk has a positive correlation with Return on Investment. This idea becomes true when the bank management take risk by relocating funds in high-riskinvestments or loans with high returns; alternatively, the theory becomes fantasy when the banks face high risk and management fails to manage its occurrence and returns.

Conversely, Bowman [45], in his paradox theory of risk and return, propounded that risk and return have a negative relation because managers aimed at increasing returns and reducing risk at the same time. In reality, this idea is true when a bank fails to manage risk, the risk is high and the profit is low, and when the bank succeeds in managing risk, the risk is low and the profit is high. Instructively, the connection between individual risk and performance has been shown by much of the empirical literature.

Starting with credit risk, Athanasoglou, Brissimis, \& Delis [10], in their study on bank-specific determinants, industry-specific determinants and macroeconomic determinants of bank profitability, used the GMM technique for a panel data model for Greek banks covering the period 1997-2013. The outcome of the study shows that financial risks but in the form of credit risk is a bank specific factor, that credit risk negatively affects the performance of conventional banks.

\section{EMPIRICAL LITERATURE \\ Financial Risks and Bank Performance}

Tafri, Hamid, Meara, and Omar [11] in their study on financial risks and profitability, examined the relationship between financial risks and profitability of conventional and Islamic banks in Malaysia for the period between 2005 and 2014. The components of financial risks in the study comprised of credit risk, interest rate risk and liquidity risk. The study employed panel data regression analysis of Generalized Least Squares (GLS) of fixed effects and random effects models and found that interest rate risk has a significant effect on ROA for the conventional banks while liquidity risk has an insignificant impact on profitability. Similarly, Ben-Naceur and Omran [11]'s studies of MENA countries about the influence of risks in commercial banks operations and profitability from 1995-2011; they found that bank - specific characteristics such as credit risk and bank capital has positive and significant impact on their profitability.

Additionally, Athanasoglou, Delis, and Staikouras [12], studied the determinants of bank profitability in the South Easter Europe region over the period 2008-2012. They applied random effect model (REM) for Generalized Least Square (GLS) estimation model since Hausman test indicates insignificant Pvalue. The results of the study show liquidity risk has 
Isedu, Mustafa et al., Saudi J Bus Manag Stud, Mar, 2021; 6(3): 71-85

positive but not a significant effect on Return on Asset (ROA) of banks, while credit risk has negative and significant effect on banks' ROA. Moreover, capital has positive and also significant effect on ROA.

Furthermore, Aruwa and Musa [13] examined the effects of risk components like credit risk, interest rate risk and operational risk on the financial performance of Deposit Money Banks in Nigeria. The study used the whole number of banks operating in Nigeria from the year 1997 to 2011. In the study the outcome showed that there is a strong relationship between the risk components and the financial performance of banks in Nigeria as indicated by the Rsquared value of $91 \%$; while credit risk and the rate of capital to total weighted risk asset have positive relationship. Operational risk and interest rate risk affects profitability negatively.

Moreover, Jamil [14], in her study examined the various types of risks (credit, liquidity, market and capital risks) which the Jordanian commercial banks are exposed to, and the strategies adopted by these banks to manage these types of risks finally appeared on Basel II Accord. The sample of the study was on 4 Jordanian banks during the period 2005-2017. The survey data method was used, and the pooled data regression method was used to analyze the data. The study outcome indicated that banks have the ability to consider and manage some types of risks, and there is statistical relationship between total risk and all types of risks. The study outcome therefore stressed that liquidity risk and credit risk have the most effect on total risk, and operational risk has the least effect on total risk compared to the other risks. However, the study failed to indicate the effect of risks on banks' performance.

In line with other studies, Imad [15], investigated the bank-specific determinants of Jordanian Islamic banks' profitability. The study employed profit margin and Return on Assets (ROA) as indicators of banks' profitability. The independent variables used were capital adequacy, credit risk, liquidity risk, management efficiency, bank size, management expenses, non-interest earnings, market concentration, bank-industry size, inflation and economic growth. The result from the study reveals that credit risk has positive impact on Islamic banks' profitability. The finding is consistent with previous researches. However, other factors such as bank size, non-interest earning and efficiency of management expenses do not has any significant effect on Return on Asset (ROA) and profit margin of these banks.

In a similar vein, the study by Fauziah Hanim, Zarinah, Ahamed-Kameel, and Mohdazmi [16], also aimed to analyze the relationship between financial risks and profitability of conventional and Islamic banks in Malaysia. They used panel data sources from 2006-
2011. In the study, bank profitability is proxy by Return on Asset (ROA), Return on Equity (ROE) and Net Interest/Income Margin (NIM), whereas the independent variables were proxy liquidity risk, credit risk, interest rate risk, interaction between credit risk and interest rate risk, off balance sheet activities, bank size, bank capital, lag of ROA or ROE and GDP growth. The outcome of the study showed that credit risk has a major effect on Return on Asset and Return on Equity of the banks. They believed the outcome might be due to the move that banks are exposed to high risk loan, the higher the Non-Performing Loan and this eventually result in the decrease of conventional banks' earnings. Meanwhile, interest rate risk affect the conventional banks Return on Equity, but the effect is weakly significant and is insignificant for Islamic banks. Moreover, liquidity risk is insignificant in affecting the banks' performance as showed by comparison relationship vis-are-vis the Return on Asset and Return on Equity for both conventional banks and Islamic banks.

In another study, Chukwunulu, Ezeabasili,and Igbodika [17], examine the effect of credit risk on bank's performance. The result of their findings show that ROA and ROE which both measure profitability, were vice versa related to Non-Performing Loan. This has caused the decreases in profitability.

Similar study by Adolphus, [14], the results outcome concur with the above, that there is a positive relationship between credit risk management and profitability, but stated that there are other factors that can impact the performance of banks especially in rural area. These are low level of income, inaccessibility to formal financial markets and also lack of information or awareness.

In addition, Kargi [18] examined the effect of credit risk on the profitability of Nigerian banks. Financial ratios were used to measures bank performance and credit risk. Data were source from the annual reports and accounts of sampled banks from 2010-2014 and analyzed using descriptive, correlation and regression techniques. The findings showed that credit risk management has a significant effect on profitability of Nigerian banks. He concluded that banks' profitability is negatively affected by banks' loans and advances, non-performing loans and deposits thereby exposing them (the banks) to liquidity risk and distress. In a similar study, Muhammed, Khizer, and Shama [19], used the same methods to investigate how credit risk affect banks' performance in Nigeria from 2006-2010. The researchers drew their samples from six Nigerian banks, while ROA was used as performance indicator, Non-Performing Loan to Loan and Advance, Loan and Advance to Total deposit were used as credit risk indicator. 
Isedu, Mustafa et al., Saudi J Bus Manag Stud, Mar, 2021; 6(3): 71-85

\section{SECTION THREE}

\section{Sources of Data Collection}

The data sourced from the Central Bank of Nigeria annual reports and statistical bulletin (various years), Central Bank of Nigeria's financial Stability Reports, Nigerian Stock Exchange (NSE) Fact books, and Financial/Accounting annual reports and Statement of Profit or Loss Accounts and other comprehensive income of the various Nigeria's deposit money banks for the period 2000 to 2019. All the deposit money banks were in operations within the study period, and have published accounts for the nineteen years period from 2000 to 2019.

\section{DATA ANALYSIS AND PRESENTATION}

This section discussed the techniques used to analyzed the data and test the variables. The data analysis involved descriptive and inferential statistics where model specification estimation was derived. The secondary data were tested for normality and transformed into natural logarithm before regression was undertaken.

\section{Techniques for Data Analysis}

The data for this paper were organized and financial ratios were used. These were computed using Excel program in order to obtain the study variables. The financial ratios to be computed for each of the deposit money banks for the study period were then transformed into panel data. Regression technique to measure, describe and analyze the effect of financial risks on the performance of deposit money banks in Nigeria.

The balanced Panel data collection and estimation technique (regression statistical technique) was adopted. Panel data is defined as a data set with a cross section and a time dimension. The observed units are followed over time (time series effects), and taken together the repeated observations of one unit constitutes a panel. Other names for it are pooled data, micro panel data, longitudinal data, event analysis and cohort analysis. Panel data is adopted because it takes care of heterogeneity associated with individual banks by allowing for individual specific variables, also all the required data are available thus there are no need for projection or forecasting. By using both time series and cross sectional observations, panel data give more informative data, more variability, less collinearity among variables, more degrees of freedom and more efficiency; especially suitable to study dynamic of change, and minimize bias due to aggregation. It also improves empirical analysis in such a way that it may not be possible if either only time series data or cross sectional data is used [20]. Panel data is also employed because; it help to study the behavior of each of the banks over time and across space and then a regression is run over these two dimensions [21, 22].
Econometrically, this paper has adopted the following equations:

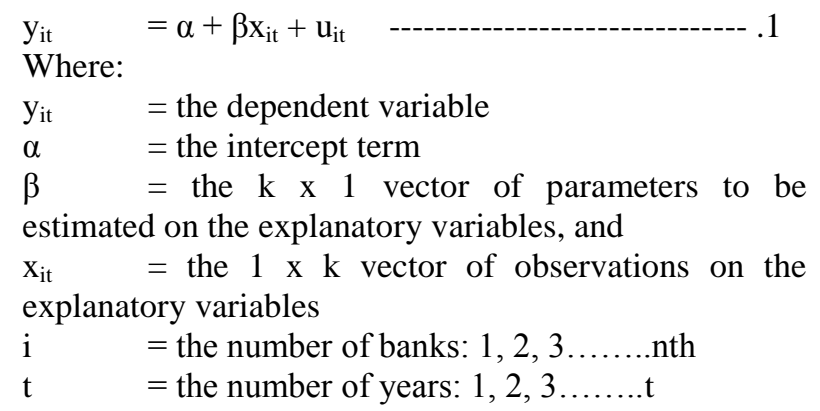

\section{Choice of Model}

Panel data analysis has three independent approaches; the first one is a pooled panel which assumes that there are no major attributes of variables within the measurement set, and no universal effects across time. The second approach is the fixed effects models which assume that there are unique attribute for models which assume the presents of unique, time constant attributes of variables that are the results of random variation (the third approach) which does not correlate with the individual regressors.

Brookings [23], specified that there are broadly two classes of panel estimator approaches that can be employed in financial research. The first one is the fixed effect model. This decomposed the disturbance term $\mu_{\mathrm{it}}$ in the equation (1) above into an individual specific effect, $u_{i}$ and the remainder disturbance; $\mu_{i t}$ that varies over time and entities (getting everything that is left unexplained about $\mathrm{y}_{\mathrm{it}}$ ). Therefore,

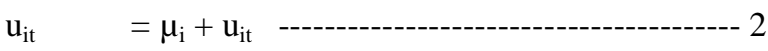

The equation (1) above could be rewritten by substituting for $\mathrm{u}_{\mathrm{it}}$ from (2) to obtain:

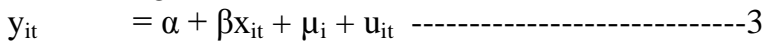

$\mu_{i}$ as encapsulating all the variables that affect $y_{i t}$ crosssectional but not vary over time can be thought of dummy variables.

Instead of an entity fixed effects model there is possibility of having a time-fixed effects model. Such a model could be used where we thought that the average value of $y_{i t}$ changes over time but net cross-sectional. Hence, with time fixed effect, the intercepts would be admitted to change in time but would be presumed to be identical across entities at each given point in time.

A time-fixed effects model could be written as:

$\mathrm{y}_{\mathrm{it}} \quad \alpha+\beta \mathrm{x}_{\mathrm{it}}+\lambda_{\mathrm{t}}+\mathrm{u}_{\mathrm{it}}$ Where:

$\lambda_{\mathrm{t}} \quad=$ is a time-varying intercept that captures all of the variables that affect $y_{i t}$ and that vary over time but are constant cross-sectionally. 
Isedu, Mustafa et al., Saudi J Bus Manag Stud, Mar, 2021; 6(3): 71-85

The second model is the random effect model which does not correlate with the individual regressors. A random effect model assumes that the unobserved difference is not correlated with explanatory variables. This model is appropriate when drawing inferences about the whole population. The benefit of using the random effects model is that regressors allowed timeinvariant variables to be included [24], since pooled regression model assumed that all the institutions are the same which is not the case. The two models cater for heterogeneity or individuality among the institutions which allows each institution to have its own intercept value which is time invariant.

In deciding which of the model (fixed effect or random effect) to employ, Al-Khouri [25], employed both the random and fixed effect regression analysis for his research on the effect of risk characteristics specific to bank on the performance of banks from the Gulf Cooperation Council (GCC) countries. But, according to Brookings [23], as to which model between the fixed and random is appropriate, is to run Haussmann test to determine the choice between the fixed and random effects approaches before regressing to address the objectives of the study, hence the Haussmann test.

\section{Haussmann Test}

The Haussmann specification test of fixed and random effects enable us to select the appropriate model for the estimation. This test compares the fixed versus the random effects under the null hypothesis than the individual effects are uncorrelated with the order regressors in the model.

The test statements are:

$\mathrm{H}_{0}$ : that the individual effects are uncorrelated with the regressors.

$\mathrm{H}_{1}$ : that the individual effects are correlated with the regressors.

If the test should give the indication that $\mathrm{H}_{0}$ is rejected, a random effect model will produce biased estimates, so a fixed effect model will be preferred.

\section{Model Specification}

The study adopted Panel data (comprising cross-sectional and time series data) regression model in line with the models on similar works by Ben-Naceur and Omran, [26]; Flamini et al., [27]; Epure and Lafuente, [28]; Athanasoglou, Brissimis, \& Delis, [10]; Ahmad and Ariff, [3]; and Kurotamunobaraomi, Giami \& Obari $[3,44]$.

The Panel regressive technique takes the form as:

$P_{i t}(R O A)=F\left(y_{i t}, z_{i t}\right)+e_{i t}$ Where:

$\mathrm{P}_{\text {it }} \quad=$ is the performance (ROA) of bank $\mathrm{i}$ at time $\mathrm{t}$.

$\mathrm{y}_{\mathrm{it}} \quad=\mathrm{is}$ the vector of variables (financial risks) characteristics of bank $i$ at time $t$.

$\mathrm{Z}_{\mathrm{it}} \quad=$ represents features of the variables, and $\mathrm{e}_{\mathrm{it}} \quad=$ is the error term.

The empirical framework for the investigation of the connection between bank performance and financial risks practice was given in the general form of panel multiple regression techniques as specified as follows:

$P_{\text {it }}(R O A)=f\left(\mathrm{CR}_{\mathrm{it}}, \mathrm{LR}_{\mathrm{it}}, \mathrm{MKTR}_{\mathrm{it}}, \mathrm{OPEXR}_{\mathrm{it}}\right)$-----------6

Equation 6 shows that potentially, DMBs' performance proxy by ROA is determined by CR, LR, MKTR and OPEXR which form a plausible relationship in order to estimate the above equation (6); where:

$\mathrm{ROA}_{\mathrm{it}}=\mathrm{is}$ the performance of bank $\mathrm{i}$ at time $\mathrm{t}$.

$\mathrm{CR}_{\mathrm{it}} \quad=\mathrm{is}$ the measures of credit risk ratios of bank $\mathrm{i}$ at time $\mathrm{t}$.

$\mathrm{LR}_{\mathrm{it}} \quad=$ is the measures of liquidity risk ratios of bank $\mathrm{i}$ at time $\mathrm{t}$.

$\mathrm{MKR}_{\mathrm{it}}=\mathrm{is}$ the measures of market risk ratios of bank $\mathrm{i}$ at time $\mathrm{t}$, and

$\mathrm{OPER}_{\mathrm{it}}=\mathrm{is}$ the measures of operational risk ratios of bank $\mathrm{i}$ at time $\mathrm{t}$.

From the above equation (6), and consistent with the study of Rao et al., [29]; and Saleem and Raheman [30], our model will maintain that bank performance proxy by ROA) is a function of financial risks proxy by:

Credit risk ROA = $\mathrm{f}(\mathrm{NPLs}$, LLPs $)$;

Liquidity risk $=\mathrm{f}(\mathrm{TL} / \mathrm{TD}, \mathrm{TL} / \mathrm{TA})$;

Market risk $\quad=\mathrm{f}(\mathrm{DFL}$, Irrr/Log NIM $)$; and

Operational risk $=\mathrm{f}($ NIMOPEX, OPEXTA $)$.

However, since one variable is to be used as dependent variable in the study, and more than one variable as independent variables also in the study, the general forms of the panel multiple regression techniques derived from equations 1-5. Thus, the empirical model specification to be estimated was stated as following:

\section{ROA Model}

ROA $=\alpha+\beta_{1}$ NPLR $+\beta_{2}$ LLPR $+\beta_{3}$ TLTD $+\beta_{4}$ TLTA + $\beta_{5} \mathrm{DFL}+\beta_{6} \mathrm{LgNIM}+\beta_{7} \mathrm{NIMOPEX}+\beta_{8} \mathrm{OPEXTA}+$ eit Where:

ROA $=$ Return on Asset;

NPLs $\quad=$ Non-Performing Loans;

LLPs $\quad=$ Loan Loss Provisions;

TLTD $\quad=$ Total Loan to Total Deposit;

TLTA $\quad=$ Total Loan to Total Asset;

DFL $\quad=$ Degree of Financial Leverage;

LgNIM $=$ Log of Net Interest Margin or measure as IRRR (that is, Interest rate risk);

NIMOPEX =Net Interest Margin to Total Operating Expenses; 
Isedu, Mustafa et al., Saudi J Bus Manag Stud, Mar, 2021; 6(3): 71-85

\begin{tabular}{llll}
\hline OPEXTAz $_{\text {it }}$ & $=$ & Operating Expenses to Total & $\begin{array}{l}\text { ROA is calculated as a percentage of net income over } \\
\text { total asset; that is: }\end{array}$ \\
Assets, and & $=$ & error terms. & ROA $\quad=\quad$ Net Income
\end{tabular}

\section{Apriori expectation}

Notwithstanding the general lack of consensus in the literature on the effect, impact or influence of financial risks on deposit money banks' performance; theory suggest that an increased exposure to financial risks is often associated with decrease in bank profitability; hence, the a' priori expectation in the model is that all the independent variables are expected to have a negative relationship on bank performance measured by Return on Asset (ROA) except bank size which is expected to have a positive relationship with bank performance. The mathematical expression is represented as $\beta_{1}-\beta_{8}<0 \quad(\alpha 1<0)$; with the only exception of $\beta_{9}$ where we expect positive relationship of $\beta 9>0(\alpha 2>0)$, implying that a unit increase in the independent variables will lead to decrease in ROA by a unit.

\section{Measurement of Study Variables and the Variables Characteristics}

The study adopted bank performance as the dependent variable; while credit risk, liquidity risk, market risk and operational risk constitute the explanatory, or independent variables for the study. This section therefore provides details of the variables characteristics, and how each of the study variables were measured and operationalized.

\section{Dependent Variable}

In our study, the dependent variable was measured by bank performance; this was proxied by Return on Asset (ROA).

\section{Return on Asset (ROA)}

ROA is considered as an inclusive measurement indicator of total bank performance and/or profitability [31]. The ROA demonstrates the levels of net income produced by banks and also determined how the assets utilized by the banks generate profits over the years [32]. In other words, the competence and proficiency of banks in transforming their assets into profits is indicated by it, hence, to improve the performance of banks, they always attempt to achieve higher ROA. ROA ratio also indicates the management efficiency in using and utilizing the company's overall assets to make or generate profit. The higher the ROA, the more efficient management is utilizing its assets base. The ranking of banks is also usually based upon the higher ROA ratio and total assets. It has also been used in similar studies by Francis [33]; Athanasoglou et al., [10]; Perera, Skully, \& Chaudhry [34]. The decision rule or criteria is that the ROA of at least $1 \%$ is good for the banking institutions.
Where:

$\begin{array}{lll}\text { ROA } & = & \text { Return on Asset. } \\ \text { Net Income } & = & \text { Profit after interest and taxes }\end{array}$

\section{Independent Variables}

In the study, our independent variables were measured by financial risks indicators (these are Credit risk, Liquidity risk, Market risk and Operational risk). And they were proxied by the following variables:

\section{- Credit Risk (Cr)}

\section{Non-Performing Loan ratio (NPLr)}

Non-Performing Loan (NPL) is a credit risk variable and an indicator of banks' poor performance. An asset becomes non-performing when the customer cannot meet the repayment agreement as at when due. Asset quality ratio is also known as NPLR, is the ratio of non - performing loans to total loans [35]. In other words, it measures the percentage of gross loans that are non-performing or doubtful in banks' loan portfolio; and shows the risk of any bank regarding its credit disbursed to the counterparty.

NPLs also entail a reputation risk to the bank. If a bank is facing problem of NPLs, then it adversely affects its credit rating and would limit its opportunities of co-financing and syndication with other banks. Thus, huge amount of NPLs may affect the profitability and can threaten the survival of commercial banks.

NPLr is computed by:
NPLr = NPL
TL

Where:

NPL $=$ Non-Performing Loan, and

$\mathrm{TL}=$ Total Loan or Gross Loan.

\section{- $\quad$ Liquidity Risk (Lr)}

The study empirically examined the nature of the relationship between liquidity and performance by using Loan to Deposit Ratio (LTDR), Loan to Total Asset Ratio (LTAR), and Cash Ratio (CR).

\section{LTA}

Loan to Total Asset (LTA or LOANTA) measures the exposure level of the banks to liquidity risk, it is thus a liquidity risk variable. LOANTA is, Total Loan as a percentage of Total Asset. Loans are larger percentage of interest earning asset of a bank. Therefore when the LOANTA ratio increases, a bank's profits increases. On the other hand a bank Liquidity risk increases when LOANTA ratio increases. In other words, banks with higher loan to total asset ratio have high exposure to liquidity risk [36, 21]. 
LOANTA ratio is measure as:

$\begin{array}{ll}\text { LOANTA }= & \text { LOAN } \\ & \text { TA }\end{array}$

Where:

$\begin{array}{lll}\text { LOAN } & = & \text { Total Loan of the bank, and } \\ \text { TA } & = & \text { Total Asset. }\end{array}$

\section{Cash Ratio (CR)}

Cash ratio is another measure of liquidity. Ibe [37], posit that the cash ratio is particularly effective for sterilizing excess liquidity at the banking system ss it can be effectively monitored by the regulating authorities. Under cash ratio, liquid assets are related directly to deposits rather than to loans and advances that constitute the most liquid illiquid of bank assets. Epetimehin, and Obafemi [28]. asserts that the main measures of liquidity in Nigeria are the Cash Reserve Ratio (CRR), the Loan to Deposit Ratio (LDR) and the Loan to Total Asset Ratio (LTAR). These are also called liquidity ratio (LR). However, cash ratio is excluded from our measuring variable because of uniformity (by applying two variables each for financial risks indicators).

\section{- $\quad$ Market Risk (MKTr)}

\section{Degree of Financial Leverage (DFL)}

The Degree of Financial leverage is a Market risk variable; and it measures the proportion of earnings before interest and taxes (EBIT) against the earnings before taxes (EBT) which shows the debt amount that a business is obligated to pay back. Bank could prosper by taking reasonable leverage risk or could become insolvent if the risk is out of control. Nevertheless, the higher the ratio is, the more risky the business is considered to be, because it relies too much on debts, and any changes within the economic environment or in interest rates may have an extremely negative impact on how the business will evolves.

The financial leverage of the firm may be computed as the ratio of earnings before interest and taxes to earnings before taxes; and/or measured as total liabilities to total assets [38, 33].

\section{That is:}

$\begin{array}{ll}\text { DFL }= & \text { EBIT OR TLi } \\ & \text { EBT TA }\end{array}$

Where:

DFL $=$ Degree of financial leverage.

EBIT $=$ Earnings before interest and taxes.

EBT $=$ Earnings before taxes.

$\mathrm{TLi}=$ Total liability, and

TA $=$ Total asset.

This mode of computation has been adopted because it focuses directly on the impact of interest on income before taxes.

\section{Interest Rate (Irr)}

Interest rate is a Market risk variable. Financial performance of deposit money banks is exposed to interest rates movements. The study captured the effect of interest rate as a measure of market risk since a change in interest rate could lead to a mismatch between interest paid on deposit and the interest received on loans. Profitability rises as interest rates rise due to a greater margin between the Central Bank's rate and the rates that are charged by a bank to its customers.

Interest rate risk factors have adverse effects on bank's earnings and its economic position which are estimated in each currency that banks have interest rate sensitive securities and off-balance sheet positions.

\section{Operational Risk (OPEXr)}

OPEXr is measure by cost income ratio (CIR), that is, the ratio of operating cost to income. OPEXr is also known as efficiency ratio. A reduction in cost for a given level of income is expected to increase profits and vice versa.

OPEXr is measured by the following indicators:

\section{NIMOPEX}

This is Operational risk variable. The index measures Net Interest Margin (NIM) as a percentage of Total Operating Expenses. The NIM is estimated by interest income minus interest expenses. It is generally expected that an efficient bank has a higher NIMOPEX than an inefficient bank. It is thus expected that $\alpha \prod / \alpha \mathrm{NIM}>0$.

\begin{tabular}{lll}
\multicolumn{2}{l}{ Operational risk is computed as } \\
NIMOPEX & $=$ & NIM \\
& & TOPEX \\
Where: & $=$ & Operational risk. \\
OPE & $=$ & Net Interest Margin, and \\
NIM & $=$ & Total operating expenses. \\
TOPEX & &
\end{tabular}

\section{OPEXTA}

OPEXTA is also an indicative of Operational risk variable. OPEXTA is operating expenses to Total assets. It is expected that when a bank has higher operating expenses per Naira assets, the profitability of the bank declines. On the other hand, when the operating expenses are directed for loans recovery, loans defaults, and asset management, it is quite possible that the higher the OPEXTA, the higher the profitability of a bank. It is thus expected that $\alpha \prod / \alpha \mathrm{OPEXTA}<\mathrm{OR}<0$. 
Isedu, Mustafa et al., Saudi J Bus Manag Stud, Mar, 2021; 6(3): 71-85

Operational risk can be computed as:

OPEXTA =OPEX

TA

Where:

OPEXTA

OPEX

TA

$=$ Operating expenses to total assets.

$=$ Operating expenses, and

$=$ Total Asset.

\section{SECTION FOUR \\ RESULTS AND DISCUSSION INTRODUCTION}

This section encompasses data analysis, presentation of results and discussion of findings. The analysis involves the use of both statistical and econometric methods to provide a rich background for investigating the effect of financial risks on deposit money banks' performance in Nigeria. The statistical tools employed were the descriptive statistics and correlation analysis. The descriptive statistics were used to provide the initial characterization of the data while the correlation analysis was used to indicate the relationship between the variables. The econometric analysis extends the statistical analysis with the goal of performing the empirical analysis and obtaining estimated coefficients which are valid enough to test the hypotheses of the study. As explained in the previous section, the Panel Data Analysis method is employed in the econometric analysis. The discussions of findings follow each of the various analyses below.

\section{DATA PRESENTATION Descriptive statistics}

Descriptive statistics show the summary of data and other basic characteristics within the series. The annualized summary statistics for the main variables in the study are presented for the sampled banks in table 4.1. below.

Table-4.1: Descriptive Statistics

\begin{tabular}{|l|l|l|l|l|l|l|l|l|l|}
\hline & Mean. & Med. & Max. & Min. & Std. Dev. & Skew. & Kurt. & J-B. & Prob. \\
\hline ROA & 0.0229 & 0.0187 & 0.7107 & -0.44791 & 0.0694 & 4.2124 & 56.959 & 42501.1 & 0 \\
\hline NPLR & 0.2351 & 0.1417 & 3.735149 & 0.00079 & 0.3435 & 6.499 & 63.639 & 54807.5 & 0 \\
\hline LLPR & 0.0977 & 0.0519 & 1.2568 & -0.3502 & 0.1394 & 3.0664 & 19.323 & 4332.9 & 0 \\
\hline LTAR & 0.5383 & 0.3307 & 11.3792 & 0.0218 & 1.2061 & 6.7382 & 51.933 & 36708.7 & 0 \\
\hline LDR & 4.2914 & 0.4232 & 381.7485 & 0.0301 & 35.097 & 10.111 & 105.45 & 155408.1 & 0 \\
\hline LEVERAGE & 4.023 & 1.605 & 43.75 & -7.19 & 5.2439 & 3.2014 & 18.812 & 4147.1 & 0 \\
\hline IRRR & 1.7628 & 1.805 & 2.315482 & 0.0723 & 0.1990 & -2.7811 & 19.679 & 4405.2 & 0 \\
\hline NIMTOPEXR & 1.5549 & 1.106 & 23.59674 & 0.0172 & 2.1471 & 6.7101 & 63.010 & 53883.7 & 0 \\
\hline OPEXTAR & 0.1183 & 0.052 & 1.342816 & 0.00158 & 0.2014 & 3.5467 & 16.683 & 3384.9 & 0 \\
\hline SIZE & 7.6109 & 7.942 & 9.81 & 4.5386 & 1.3673 & -0.4489 & 1.9200 & 28.1064 & 0.001 \\
\hline
\end{tabular}

Source: Author's computation (2019)

The mean value is $\$ 0.0229$ million Naira for the entire sample of 342 . The data appears to be skewed to the right, which explains why the mean is greater than the median value of 0.0187 . This was further confirmed by the skewness coefficient of 4.2124 which indicated that the distribution was positively skewed to the right, which was a common feature of the return on asset.

The maximum value of the entire sampled firms' performance was about $\$ 0.7107$ while the minimum value is -0.44791 . With this result, more firms are seen to perform very well within the periods, while others did not. This is while the minimum ROA (performance) value is less than -0.44791 .

There appeared to be quite a lot of variations in the financial performance of the sampled banks, the standard deviation value of 0.0694 is very large compared to the mean value of 0.0229 . This simply suggests a high level of variability of the pattern of financial performance either across the banks or overtime within banks.
The summary statistics with respect to JaqueBera (J-B) statistic value of 42501.1 for the financial performance variable is significant at the 1 percent level and implies that the probability distribution of the sample for the variable is not normally distributed. This invariably suggests that the financial performance across the sampled banks is heterogeneous and exhibit firm-specific characteristic. This is one justification for the application of the panel data estimation technique in this study.

The descriptive statistics for the other variables in the study also present interesting outcomes. For the banks' credit risk factor represented by (NPLR and LLPR), the mean and maximum values (NPLR $0.2351,3.735149$ and LLPR $0.0977,1.2568$ ) clearly show that on average, credit risk liabilities are higher than financial performance for the Nigerian banking industry. The degree of variability is also very high among the banks, although the skewness values of (6.499 and 3.0664) is positive, indicating that more banks are faced with higher credit risk than the reported mean value for the period of the sample. The J-B statistic values (54807.5 and 4332.9) for both variables representing credit risk are significant at the $1 \%$ level. 
Isedu, Mustafa et al., Saudi J Bus Manag Stud, Mar, 2021; 6(3): 71-85

These also indicate non-normal distribution, an indication of heterogeneity in the pattern of credit risk liability by the banks. Indeed, all the variables in the study had highly significant J-B values, clearly showing that individual firm/bank characteristics are quite important in the measurement of the variables.

The average bank liquidity risk as measured by loan to deposit ratio (LDR) and liquidity ratio risk (LRR) for the sampled period is $(0.5383,4.2914)$ with corresponding high maximum values of (11.3792 and 381.7485). The standard deviation values of 51.933 and 105.45 also show that, there is a large spread in liquidity risks among the sampled banks.

The mean value of market risk as measured by degree of financial leverage (DFL) and interest rate risk (IRR) are 4.023 and 1.7628, while their respective maximum values are 43.75 and 2.315. The maximum values' being higher than the mean values is an indication that more banks in Nigeria are facing market risk than others. The standard deviation value of 5.2439 is very large, suggesting a high level of variability of market risk across the banks overtime.

The mean value of bank size is \$7.6109 billion, with maximum value reaching over $\$ 9.81$ billion. There appeared to be minimal variations in the assets of banks, the standard deviation is very low as compared to the mean value across the sampled banks in the study. Although the skewness value is negative (0.4489), indicating that few banks have assets that are lower than the reported mean value for the period of the sample. The J-B statistic also shows non-normal distribution, an indication of heterogeneity in the pattern of banks' assets within the period of investigation.

Econometric analysis (the panel models)

Table-4.3: Financial Risks and Deposit Money Banks' Performance Estimates (Dependent Variable $=$ ROA)

\begin{tabular}{|c|c|c|c|c|c|c|}
\hline \multirow[b]{2}{*}{ Variable } & \multicolumn{2}{|c|}{ Fixed Effects(EF) } & \multirow[b]{2}{*}{ Prob. } & \multicolumn{2}{|c|}{ Random Effects(RE) } & \multirow[b]{2}{*}{ Prob. } \\
\hline & Coeff. & t-Stat. & & Coeff. & t-Stat. & \\
\hline Constant & 0.048496 & 1.367957 & 0.1723 & 0.017211 & 0.506908 & 0.6126 \\
\hline NPLR & 0.000591 & 0.039761 & 0.9683 & -0.011961 & -0.854318 & 0.3935 \\
\hline LLPR & 0.012774 & 0.311769 & 0.7554 & 0.028398 & 0.840112 & 0.4014 \\
\hline LTAR & 0.027486 & 4.054654 & $0.0001 * *$ & 0.029272 & 4.620770 & 0.0000 \\
\hline LDR & -0.000781 & -3.772419 & $0.0002 * *$ & -0.000862 & -4.248047 & 0.0000 \\
\hline LEVERAGE & -0.000409 & -0.442347 & 0.6585 & -0.001686 & -2.451921 & 0.0147 \\
\hline IRR & -0.020786 & -1.059575 & 0.2901 & 0.000624 & 0.033285 & 0.9735 \\
\hline NIMTOPEXR & -0.002661 & -1.448775 & 0.1484 & -0.001822 & -1.002575 & 0.3168 \\
\hline OPEXTAR & 0.033955 & 1.375071 & 0.1701 & 0.018611 & 0.855150 & 0.3931 \\
\hline R-squared & 0.666 & & & 0.095 & & \\
\hline Adj. R-squared & 0.612 & & & 0.073 & & \\
\hline F-statistic & 9.212 & $\mathrm{DW}=1.97$ & & & 4.3602 & $\mathrm{DW}=1.59$ \\
\hline
\end{tabular}

Source: Author's computation (2019) Note: **1\% level of sig; * 5\% level of sig. of the relationships were performed in robustness in the analysis. Moreover, initial test of the appropriate estimation pattern for the models was conducted. The standard test for the method of panel analysis adopted is the Hausman test for random effects. But since the biases in the pooled data could either come from cross sectional heterogeneity or time series (periodic) changes, the Hausman test reported in table 4.2 below was conducted to determine the best effects model to be adopted; the Chi-square statistic values for each of the models was significant. From the results, the statistic provides little evidence against the null hypothesis that there is no misspecification when the Fixed-effect model is employed for the estimates in values. Hence, the best method to apply for the model estimation was the Fixed-effect strategy.

Table-4.2: Hausman Test for Panel Effects

\begin{tabular}{|c|c|c|c|}
\hline Test Summary & $\begin{array}{c}\text { Chi-Sq. } \\
\text { Statistic }\end{array}$ & $\begin{array}{c}\text { Chi-Sq. } \\
\text { df. }\end{array}$ & Prob. \\
\hline $\begin{array}{c}\text { Cross-section } \\
\text { random }\end{array}$ & 23.0892 & 8 & 0.0033 \\
\hline
\end{tabular}

Source: Author's computation (2019)

\section{Estimation with DMBs Performance and Financial Risks Related Factors}

The first set of analysis of the results is the estimation of the aggregate behaviour of deposit money banks (DMBs) financial performance in the face of changes in financial risks related factors (model 1). Though the Hausman test has shown that the Fixed Effects (FE) estimates are more appropriate in the estimations, we include Random Effect (RE) estimate for the sake of robustness checks.

\section{ROA Model: Estimation with DMBs Performance and Financial Risks}

The result of the estimates of deposit money bank of the model with the basic bank's financial risks is computed is reported in Table 4.3 below. 
Isedu, Mustafa et al., Saudi J Bus Manag Stud, Mar, 2021; 6(3): 71-85

The coefficient of determination $\left(\mathrm{R}^{2}\right)$ value is. 66653 , this implies that 67 per cent of the total variation in return of assets is explained by changes in the explanatory variables. Subsequently, 33 per cent is unexplained due to error term. The adjusted coefficient of determination $\left(\mathrm{R}^{-2}\right)$ Value of. 61226 implies that 39 per cent of the total variation in return on asset is explained by changes in the explanatory variables when the coefficient of determination is adjusted for degree of freedom. This implies that 39 per cent is unexplained due to error term. Durbin Watson Statistic of 1.97 for the fixed indicates that there is absence of serial autocorrelation. The $\mathrm{F}$ - test with a value of 9.21 suggests that the variables are significant factors to be considered in changing the level deposit money bank performance.

The relevance of each of the variables in the model is determined by considering the individual coefficients of the variables in terms of significance and signs $[24,16]$.

A close examination of the individual coefficients in the model revealed that, credit risk measured by non-performing loans ratio (NPLR) failed the significance test at the 5 percent level, because it is not statistically significant as shown by the probability value 0.3935 . Even though the coefficients are positive, they do not have any significant impact on deposit money banks' financial performance in the country. One probably reason for this insignificant effect is connected with the overwhelming response of banks to the findings of Basel accord (Bank Committee on Banking Supervision), that indicated credit risk as the greatest risk faced by the banking firms, thus banks overtime have taken drastic measures, set up modalities and techniques during the mid-1980s to 1990 s to curb and reduces credit risk exposures in their investment loan portfolios.

Liquidity risk is in line with the positive apriora expectation in the model. The coefficient of total loan to total asset ratio (TLTAR) or loan to total asset ratio (LTAR) is rightly signed which is in line with the positive apriora expectation in the model. In terms of the individual relevance, both variables (loan to total asset ratio (LTAR) and loan to deposit ratio (LDR)) are significant at the $1 \%$ level. This means that, in the determination of performance of deposit money banks in Nigeria, liquidity risk (Lr) as measured by these two variables, is a relevant factor to be considered in this regard. Indeed, it is seen that a unit increase in level of loan to total asset ratio (LTAR) leads to about $27 \%$ increase in the overall performance of banks. One probable reason for this, is not unconnected with the fact that DMBs in Nigeria overtime have been able to effectively utilize the loan portfolio of their total assets for more productive and assets yielding investments which in turn provided enough liquidity for the banks and hence, better performance. On the other hand, a unit increase in loan to deposit ratio (LDR) will decrease bank's performance by $-0.000781 \%$. The reason for this could be that the bank management is not efficient in the management of credit facilities to customers. Most of the loans issued to borrowers may have ended up as bad debt or irrecoverable loans or as non-performing loans; this further weakened the liquidity position of the banks thus, resulting in negative performance. Hence, banks' management should therefore efficiently manage the loan aspect of their portfolio in relation to assets and deposit liabilities in order to achieve stated objectives.

The market risk (MKTr) variable as measured by degree of financial leverage (LEVERAGE) and interest rate risk (IRR) is negatively signed. From the fixed effect result, degree of financial leverage (LEVERAGE) is negative and failed the 5\% level of significance as shown from the probability value 0.0147 , as it does not have any significant relationship with bank performance. Leverage represents degree of financial risks, and the higher the ratio, the more risky the bank; since it relies too much on debts, and any changes within the economic environment or in interest rates may have extreme negative impact on banks' financial performance. By implication, this result has shown that irrespective of the level of leverage employed by banks in Nigeria, it does not have any significant impact on performance.

The coefficient of interest rate risk (IRR) is also negative and failed the $5 \%$ level of significance. This means that, the level of interest rate has insignificant inverse relationship with deposit money banks' performance in Nigeria. Theoretically, changes in interest rate should lead to a mismatch between interest paid on deposit and the interest received on loans. This view was also corroborated by OpokuAdarkwa [39] that, interest rate risk factor has adverse effect on bank's earnings and economic position, estimated in each currency that banks have interest rate sensitive securities and off-balance sheet positions. In a nut-shell, market risk (MKTr) is not a relevant factor in the determination of deposit money banks' performance in Nigeria within the period of investigation. The reasons attested to the non-effect of market risk on Deposit Money Banks' performance in Nigeria are that the high exchange rate/depreciation of our currency visare-vis the dollar and followed by interest rate variations that have skewed against banks lending to foreign trade have made banks to drastically reduces their loan extension to this sector - the real sector (oil sector) of the economy.

Also, the categorization of Nigeria's Deposit Money Banks into Local, Regional, National and International services providers by the Central Bank of Nigeria (CBN) have help to rendered this risk insignificant. By this arrangements, the Microfinance Banks are meant to operates on the local level, while the deposit money banks whose capitalization value are not 
Isedu, Mustafa et al., Saudi J Bus Manag Stud, Mar, 2021; 6(3): 71-85

too strong but not less than $\$ 25$ Billion were made to operates on the regional levels (that is, those with few branch networks), for example, WEMA Bank. Others whose capitalization value where between $\$ 30$ Billion and above, and with more branch networks, operates nationally, for example, Unity Bank, Fidelity Bank, etc, those whose capitalization value were 150 Billoin and above could operate internationally. With such arrangements, not all the Nigeria's deposit money banks operates internationally, and thus could avoid the significant negative effect of market risk on performance. Also in addition to this, is the quarterly use of the Monetary Policy Rate (MPR) to guide against interest rate volatility? This arrangement has also help to cushions interest rate risk on deposit money banks' performance.

In the study, banks operational risk is measured by net interest margin to total operating expenses (NIMTOPEXR) and operating expenses to total assets (OPEXTAR). With respect to NIMTOPEXR, it is expected that an efficient bank should have a higher NIMOPEX than an inefficient bank. But higher operating expenses will reduce profitability of bank, except where it is specifically directed at loans recovery, loans defaults, and asset management. The results from the empirical analysis indicate that while the coefficient of net interest margin to total operating expenses (NIMTOPEXR) is negative, operating expenses to total assets (OPEXTAR) is positive. However, both coefficients failed the 5\% significance level. The implication of this result is that, banks operational risk does not have significant impact on the performance of deposit money banks in Nigeria.

The result has confirm that even though there is high ratio of NPLs in the Nigeria DMBs, some measures put in place by the Central Bank of Nigeria has help to cushions the significant effect of Operational risk on performance. For example, the CBN code named project 'EAGLES', This project was aimed at refocusing the banks' operational capabilities through the inculcation of changes in the working culture of staff by the adoption of appropriate work incentives, acquisition of skills and modern technology (ICT) that will yield efficiency, gains and enhance productivity growth.

\section{Discussion of Findings}

The core function of deposit money banks today is purely the efficient management of their risks portfolio investments in order to maximize shareholders' wealth, by guaranteeing safety, returns on depositors' funds and confidence in the system. Risk management in the banking sector is basically defined as the logical development and execution of a plan to deal with potential losses. Since the business of banking is regarded as risky business, there is the need to focus on their risks management practices in order to effectively and efficiently manage their exposure to losses or risks as well as to protect the value of assets. Also, the importance of the banking system is based on the fact that it ensures intermediation of funds or transferring necessary funds from the surplus unit to the deficit unit of the society. This process therefore imposes some inherent risks to the sector. These inherent risks come in different types such as credit risks, liquidity risks, market risks, operational risks among others.

Now, with respect to credit risk, the empirical result has shown that there is no significant relationship between credit risk and deposit money bank performance. It is argued in the extant literature that, for every credit or loan issued by the bank, there is a perceived risk involved. This risk refers to the possibility of non-payment of the obligation when it falls due. In this study, credit risk was proxied by nonperforming loans ratio (NPLR) and loan loss provisions ratio (LLPR). The findings from this paper agree with those of Kithinji [18] in Kenya who did not find strong positive relationship between credit risk and financial performance of banks. The findings however disagreed with those of Al-Tamimi and Jamil [7], Imad [15], Fauziah Hanim, Zarinah, Ahamed-Kameel, \& Mohdazmi [16], Tafri, Hamid, Meara, \& Omar [40] who submitted strong positive relationship between credit risk measured by (Non - Performing Loan to Gross Loan (NPL/GL), Loan Loss ratio to Non Performing Loan (LLR/NPL)) and bank financial performance. The study does not also agree with those of credit risk (NPGL, LLRGL), Musyoki and Kadubo [41], Al-Tamimi and Al-Mazrooei [7], who variously submitted significant negative relationship between credit risks and bank financial performance.

As it relates to liquidity risk (proxied by loan to total asset ratio (LTAR) and loan to deposit ratio (LDR)), Ibe [37] rightly argues that, liquidity plays a vital role in the successful functioning of a business firm; firm should therefore ensure that it does not suffer from lack of or excess liquidity to meet its short-term compulsions. Thus, the empirical findings from this study has clearly shown that the two measures of liquidity risk, loan to total asset ratio (LTAR) and loan to deposit ratio (LDR) are the major factor influencing bank financial performance in Nigeria. Indeed, while loan to total asset ratio (LTAR) is seen to be positively related, loan to deposit ratio (LDR) is negatively related with bank financial performance. This finding corroborated the studies of Tafri et al., [12], Jamil [42], Saleem \& Rehman [30] who find significant positive relationship between liquidity risk and bank performance. These findings however disagreed with those of Fauziah Hanim, Zarinah, Ahamed-Kameel, \& Mohdazmi [16], who find no significant relationship between liquidity risk and bank financial performance in their respective countries. 
Isedu, Mustafa et al., Saudi J Bus Manag Stud, Mar, 2021; 6(3): 71-85

Market risk is a dominant source of income fluctuations in the banking system which comprises exchange rate, inflation and interest rate risks. It significant influence bank's financial performance. Usually, market risks are outside the control of the banks as they are determined by factors that affect the overall economy [13].

The operational risk variable was measured by net interest margin to total operating expenses (NIMTOPEXR) and operating expenses to total assets (OPEXTAR). Operational risk relates to the issues of precisely processing, settling and taking delivery on trades for the exchange of cash. From this current study, it is seen that operational risk does not have any significant impact on the overall performance of banks in Nigeria.

In this study, bank size (BSIZE) is measured as the log of total assets of the deposit money banks. It is the only variable that serves as a control or moderating variable. From the empirical result, bank size does not have any significant effect on the financial performance of deposit money banks in the country within the period of investigation. It was observed that bank size though negative, but failed the 5 percent significance test. This means that, the size of bank with respect to the total assets base is not a significant factor in the determination of financial performance of bank in Nigeria. This finding does not however conform to some existing findings in this regard [7, 42] which submitted significant positive relationship with financial performance. It however agree with those of Imad [15], Akhtar [39], and Awojobi et al. [43], who submitted that bank size does not have any significant impact on the financial performance of deposit money banks.

\section{SECTION FIVE \\ SUMMARY, CONCLUSION AND RECOMMENDATIONS}

This chapter presents the summary of major findings of the study, relevant discussions, conclusions and the necessary recommendations. The summary is done in line with the objectives of the study based on the output of statistical analyses guided to test the research hypotheses of the study. The chapter also suggests areas for further research works.

\section{Summary and Conclusion}

The study empirically investigated the effects financial risks on the performance of deposit money banks (DMBs) in Nigeria. More specifically, changes in financial performance were examined on the basis of the relative effect of credit risk, liquidity risk, market risk, operational risk and bank size. The study specifically focused on 18 deposit money banks listed on the floor of the Nigerian Stock Market for a period of 19 years (2000 to 2019) and whose operations commenced prior to the year 2000. Both statistical and econometric techniques were applied in the analysis of the data used in the study. In particular, the Panel data analysis technique was used in the estimation of the specified models. The fixed effects being the best performing effect in the relationships was adopted in the empirical analysis. The findings of this study revealed that the combined effects of financial risks do not influence banks' performance negatively. More specifically, the results from the empirical analysis revealed as follow, that:

i) Credit risk (measured by non-performing loans ratio (NPLR) and loan loss provisions ratio (LLPR) does not have any significant relationship with financial performance of deposit money banks in Nigeria. As it is seen to have failed the $5 \%$ significance level,

ii) Liquidity risk (measured by loan to total asset ratio (LTAR) and loan to deposit ratio (LDR) passes the 5 percent level of significance. Meaning that this variable is a significant determinant of deposit money banks' performance in Nigeria in the period under investigation,

iii) The effect of market risk (MKTr) on the performance of deposit money banks in Nigeria is not significant. Market risk variables were measured by degree of financial leverage (LEVERAGE) and interest rate risk (IRRR). But from the empirical investigation, it was observed that the two measures for market risk (MKTr) do not in any way affect bank performance significantly in Nigeria at the 5\% level of significance,

iv) Operational risk (proxied by net interest margin to total operating expenses (NIMTOPEXR) and operating expenses to total assets (OPEXTAR)) do not have significant effect on deposit money banks performance in Nigeria. The two variables proxied for operational risks failed the $5 \%$ significance level,

\section{Recommendations}

On the bases of the outcome of the empirical analysis of this study, the following useful recommendations for policy initiations, implementations, enforcements and directions should be made:

i. Credit risk as measured by non-performing loans ratio (NPLR) and loan loss provisions ratio (LLPR) are positive and do not have significant impact on performance. The possible explanation for this could be that banks in Nigeria overtime, and because of the nature of their environment have been able to manage their credit system well by making adequate provisions which also serve as shock absorber to mitigate the adverse effect of nonperforming loans ratio (NPLR). Therefore, a more robust credit risk management systems 
Isedu, Mustafa et al., Saudi J Bus Manag Stud, Mar, 2021; 6(3): 71-85

that is fully in compliance with CAMELs and the prescribed ratio as provided by the regulatory institution (Central Bank of Nigeria), should be vigorously pursued in this regard.

ii. In line with the recommendation of Chukwunulu, Ezeabasili \& Igbodika [17], this study also recommends that bank's management and the Central Bank of Nigeria (CBN) should not only formulate policies on risk management, but should also do well by taking proactive steps to enforce risk identification, assessment, measurement and necessary control mechanisms in line with global best practices in other to avoid financial crisis and thus, assure deposit money banks' overall performance at any given time.

iii. Among the financial risks indicators hypothesized in this study, liquidity risk (measured by loan to total asset ratio (LTAR) and loan to deposit ratio (LDR) is the most singular important predictor of deposit money banks' performance in Nigeria. Since liquidity risk is very core to banks' performance, management should continuously lay more emphasis on liquidity risk management in order to ensure that banks have adequate cash to meet the yearnings of depositors daily, and by so doing, prevent loss of confidence, panic withdrawals and eventual bank failure. Thus, to avoid liquidity crisis, the banks' policy should be centered on the use of derivative instruments.

iv. The study further recommends that since liquidity levels had a positive effect on performance and has being noted as the greatest of the risk affecting the DMBs' performance in Nigeria, the DMBs should maintain their levels of liquidity over optimal levels. Further, the study recommends that the regulators of DMBs should be cautious about increasing the minimum liquidity ratio as this can adversely affect the performance of the DMBs.

v. Though the result from the study has shown that operational risk (proxied by net interest margin to total operating expenses (NIMTOPEXR) and operating expenses to total assets (OPEXTAR) is not a major factor affecting bank performance in Nigeria; management and relevant policy makers should endeavor to constantly initiate appropriate policies that will either sustain or improve on the current operational strategy in place in order to achieve greater operational efficiency. Thus, there should be regular training and re-training for financial institutions employees to enable them acquires the latest skills on their very sensitive job. vi. Management should focus more on the issue of cost control measure that will lead to lower operating expenses ratio, thereby leading to higher profit margins. If frequent small losses in bank's daily operations, usually caused by its inability to leverage its fixed cost are not proactively checkmated, bank's failure is imminent.

vii. The study also recommends that ROA should not form the only key criteria for evaluating the performance of banks but rather other key variables should be introduced. These include Return on Equity (ROE), Return on Capital Employ (ROCE), Net Interest/Income Margin (NIM), Basel Accord compliance, etc, and

viii. Since bank size does not have significant impact on performance, management should diverse a better means to properly redirect bank's assets for productive investment so that it can have the much needed positive impact on the overall performance of deposit money banks in Nigeria. The reason being that, better utilization of bank's assets will results in economies of scale, thereby leading to a healthier banking system by eliminating inefficiencies and reducing risks.

\section{Contribution to Knowledge}

The study contributed to knowledge in the following ways:

i. The study also added a new clause to existing findings in the extant literature. Contrary to finding from other studies, this study has demonstrated that irrespective of the assets or size of a bank, it does not in any way determine its overall performance, what rather matters is the issue of liquidity risk; and

ii. The study provides more evidence on the factors that determine financial risks for deposit money banks in Nigeria, it considers both bank-specific factors and macroeconomic determinants of financial risks, and finally, it evaluates how these factors affect the performance of commercial banks in Nigeria.

\section{Suggestions for Further Studies}

Since we have extensively investigated the impact of financial risks on the performance of deposit money banks (DMBS) in Nigeria, we suggest that further comparative studies should be carried between Nigeria and any other countries in Sub Saharan Africa, or between Nigeria and any country in Europe or America, this will enable us seen the various effects of the hypothesized variables on bank performance.

Also, other control variables outside the bank size that was used in this study could also be added. For instance, firms growth, inflation, firms age, total assets 
Isedu, Mustafa et al., Saudi J Bus Manag Stud, Mar, 2021; 6(3): 71-85

among others could also serve as moderating or control variables.

Finally, in this study, we have used panel data analysis as the main method of investigation. However, we suggest that the generalized methods of moment (GMM) which seems to be superior to the panel data analysis should be employed in this study. By so doing we will be able to effectively compare the results from both methods.

\section{REFERENCES}

1. Shanmugan, B., \& Bourke, P. (2015). The management of financial institutions: selected readings. Pub. Addison, Wesley.

2. Sufian, F., \& Chong, R. (2014). Determinants of banks' profitability in a developing economy: empirical evidence from Phillipines. Journal of Acounting and Finance, 4(2), 91-112.

3. Ahmad, N.H., \& Ariff, M. (2016). Multi-country study of bank credit risk determinants. International Journal of Banking and Finance, 5(1), 135-152.

4. Bryant, K. (2015). The integration of qualitative factors into expert system for evaluating agricultural loans. Paper presented at the Australiasian Conference on Information System.

5. Boyd, J.H., \& De Nicolo, G. (2013). The theory of bank risk-taking and competition revisited. Journal of Finance, 60(6), 1329-1343.

6. Brown, B., \& Harvey, C. (2015). Banking in Africa. James Currey Ltd, USA.

7. Al-Tamimi, H., Hussein, A., Miniaoui, H., \& Elkelish, W.W. (2015). Financial risk and Islamic banks' performance in the Gulf Cooperation Council Countries. The International Journal of Business and Finance Research, 9(5), 103-112.

8. Hawley, F. B. (1893). The risk theory of profit. The Quarterly Journal of Economics, 7(4), 459-479.

9. Aaker, D.A., \& Jacobson, R. (1987). The role of risk in explaining differences in profitability. The Academic Management Journal, 30(2), 277-296.

10. Athanasoglou, P., Brissimis, S. N., \& Delis, M.D. (2014). Bank specific, industry specific and macroeconomic determinants of bank profitability. MPRA Paper, 153, 18-43

11. Erhabor, O. J. (2020). Credit risk and the performance of deposit money banks in Nigeria.

12. Athanasoglou, P., Delis, D., \& Staikoras, C. (2016). Determinants of bank profitability in the south eastern European region. Bank of Greece. Working Paper, 47, 10-27.

13. Aruwa, S.A., \& Musa, O.A. (2014). Risk components and the financial performance of deposit money banks in Nigeria. International Journal of Social Sciences and Entrepreneurship, 1(11), 514-522.

14. Adolphus, T.J. (2018). Modeling bank management, rural lending and small business finance in Nigeria. Global Journal of Management and Business Research, 11(7), 241-267
15. Imad, Z.R. (2018). Bank-specific determinants of Islamic banks' profitability: an empirical study of Jordanian market. International Journal of Academic Research, 3(6), 73-80.

16. Fanziah Hanim, T., Zarinah, H., Ahmed, M.M., \& Mohdazmi, O. (2018). The impact of financial risk in profitability of Malaysian commercial banks (2004-2013). International Journal of Social and Human Sciences, 3, 807-821.

17. Chukwunulu, J.I., Ezeabasili, V.N., \& Igbodika, M.A.N. (2019). Risk management and the performance of commercial banks in Nigeria (1994-2016). HARD International Journal of Banking and Finance Research, 5(1), 64-71.

18. Kithinji, A.M. (2015). Credit risk management and profitability of commercial banks in Kenya. School of Business. University of Nairobi. Nairobi.

19. Muhammad, A.F., Khizer, A., \& Shama, S. (2012). Liquidity risk management: a comparative study between conventional and Islamic banks of Pakistan. Interdisciplinary Journal of Research in Business, 1(1), 25-44.

20. Ogboi, C., \& Unuafe, O. (2013). Impact of credit risk management and capital adequacy in the financial performance of commercial banks in Nigeria. Journal of Emerging Issues in Economics, Finance and Banking, 2(3), 703-717.

21. Baltagi, B. (2005). Econometrics analysis of panel data. Chichester, John Wiley and Sons Ltd.

22. Gujarati, D. N., \& Porter, D. C. (2003). Basic econometrics (ed.). Singapore: McGrew Hill Book Co.

23. Brookings, S.C. (2013). Introductory econometrics for finance. $2^{\text {nd }}$ Ed. Cambridge University Press, New York.

24. Greene, W.H. (2012). Econometric analysis. Pearson education, India.

25. Al-Khouri, R. (2016). Assessing the risk performance of the GCC banking sector. International Journal of Finance and Economics, 65, $72-78$.

26. Ben-Naceur, S., \& Omran, M. (2012). The effects of banks' regulation, competition and financial reforms on MENA banks' profitability. Working Paper. Economic Research Forum, 65.

27. Bini, G., \& Flamini, F. (2012). Finite commutative rings and their applications (Vol. 680). Springer Science \& Business Media.

28. Epetimehin, F., \& Obafemi, F. (2015). Operational risk management and the financial sector: an overview. International Journal of Economic, Commerce and Management, 3(3), 86-103.

29. Rao, A., Schoenenberger, M., Gnecco, E., Glatzel, T., Meyer, E., Brändlin, D., \& Scandella, L. (2007, April). Characterization of nanoparticles using atomic force microscopy. In Journal of Physics: Conference Series (Vol. 61, No. 1, p. 192). IOP Publishing. 
30. Saleem, Q., \& Rahaman, R.A. (2016). Impact of liquidity ratios on profitability. Interdisciplinary Journal of Research in Business, 1(7), 95-98.

31. Sinkey, Jr., \& Joseph, F. (2011). Commercial bank financial management in the financial service industry. $5^{\text {th }}$ ed, Prentice-Hall, International Inc, New Jersey.

32. Golin, J., \& Delhaise, P. (2013). The bank credit analysis handbook: a guide for analysts, bankers and investors. $2^{\text {nd }}$ Ed. John Wiley and Sons.

33. Mehari, D., \& Aemiro, T. (2013). Firm specific factors that determine insurance companies performance in Ethiopia. European Scientific Journal, 9(10), 245-255.

34. Perera, S., Skully, M., \& Chaudhry, Z. (2013). Determinants of commercial banks profitability: South Asian evidence. Asian Journal of Finance and Accounting, 5(1), 365-380.

35. Yang, C. (2010). Service, investment and risk management performance in commercial Banks. The Service Industries Journal, 32(12), 2005-2025.

36. Brewer, J., \& Hunter, A. (1989). Multimethod research: A synthesis of styles. Sage Publications, Inc.

37. Ibe, S.O. (2015). The impact of liquidity management on profitability of banks in Nigeria Journal of Finance and Bank Management, 1(1), 37-48.

38. Nikhhik, B., \& Kingshuk, I.R.M. (2015). Factors determining financing performance of life assurance companies of India: an empirical study. EPRA International Journal of Economic and Business Review, 2(8), 42-48.

39. Opoku-Adarkwa, R. (2011). Risk management and bank performance: a case study of First Atlantic Merchant Bank Ghana Limited (FAMBL) (Doctoral dissertation).

40. Erhabor, O. J. (2020). Credit risk and the performance of deposit money banks in Nigeria.

41. Musyoki, D., \& Kadubo, A. (2018). The impact of credit risk management on the financial performance of banks in Kenya. International Journal of Business and Public Management, 2(2), 72-80.

42. Jamil, M. I., Ali, A., Haq, F., Zhang, Q., Zhan, X., \& Chen, F. (2018). Icephobic strategies and materials with superwettability: design principles and mechanism. Langmuir, 34(50), 15425-15444.

43. Awojobi, O. (2011). Microfinancing for poverty reduction and economic development: A case for Nigeria. International Research Journal of Finance and Economics, (72), 159-168.

44. Kurotamunobaraomi, T., Giami, I.B., \& Obari, O.B. (2017). Liquidity and performance of Nigerian banks. Journal of Accounting and Financial Management, 3(1), 142-158.

45. Bowman, R. G. (1979). The theoretical relationship between systematic risk and financial (accounting) variables. The Journal of Finance, 34(3), 617-630. 